\author{
世界一のろい魚 ニシオンデンザメの泳ぐ速さと尾びれの振りの速さ

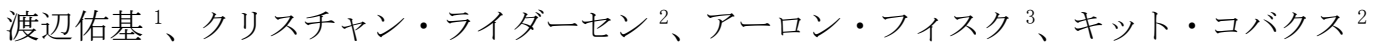 \\ 1 国立極地研究所 \\ 2ノルウェー極地研究所 \\ 3 ウィンザー大学
}

\title{
The slowest fish: swim speed and tailbeat frequency of Greenland sharks
}

\author{
Yuuki Watanabe ${ }^{1}$, Christian Lydersen ${ }^{2}$, Aaron Fisk ${ }^{3}$ and Kit Kovacs ${ }^{2}$ \\ ${ }^{1}$ National Institute of Polar Research \\ ${ }^{2}$ Norwegian Polar Institute \\ ${ }^{2}$ Univiersity of Windsor
}

Locomotory muscle function of ectothermic fishes is generally depressed in cold waters, making them vulnerable to avian and mammalian predators whose body temperature remains high. Paradoxically, Greenland sharks Somniosus microcephalus exhibit the reverse of this usual predator-prey thermal pattern by apparently hunting seals in Arctic waters. To examine whether this species possesses cold-adaptations that enhance its swimming performance, we used data-logging tags to measure swim speed and tail-beat frequency (which reflects muscle-shortening speed) of six free-swimming sharks (204-343 kg). For comparison, we compiled these parameters for wild fishes from the literature over a wide body mass range $(0.2-3900 \mathrm{~kg})$ and examined the scaling relationships using phylogenetically informed statistics. The sharks cruised at $0.34 \mathrm{~m} \cdot \mathrm{s}^{-1}$ with a tail-beat frequency of $0.15 \mathrm{~Hz}$, both of which were the lowest values for their size across fish species. The mean and maximum speed $\left(0.74 \mathrm{~m} \cdot \mathrm{s}^{-1}\right)$ and acceleration during burst swimming $\left(0.008 \mathrm{~m} \cdot \mathrm{s}^{-2}\right)$ were much lower than those of seals. Our results indicate that the swimming performance of Greenland sharks is limited by cold waters $\left(\sim{ }^{\circ} \mathrm{C}\right)$ and insufficient to catch swimming seals. However, Arctic seals sleep in water to avoid predation by polar bears Ursus maritimus, which may leave them vulnerable to this cryptic slow-swimming predator. 